\title{
Adrienn, Tengely
}

Eszterházy Károly University Department of Andragogy and General Education tengely.adrienn@uni-eszterhazy.hu

\section{TYPES OF THE AUTONOMOUS LEARNING IN THE LIGHT OF HISTORICAL SOURCES}

\section{Introduction}

Autonomous learning is the least researched and accordingly the slightest revealed type of the different ways of learning. Autonomous learning is when the learner himself initiates learning and he performs an independent, directed learning programme on the basis of his own decision: investigates the topics that raised his interest, checks his existing knowledge or refreshes his earlier gained knowledge. It is rather difficult to measure and evaluate the process and result of informal and autonomous learning connected to it. In Hungary the first survey that covered also this was carried out in 2003 among the adult population, then in 2009 another survey was made, containing more than a thousand samples. ${ }^{1}$

In certain cases we can examine the methods of autonomous learning in historical perspectives as well, we can even state its effectiveness, which can give help in the interpretation of the present surveys as well. Naturally, this is mainly possible in case of those persons whose lives we have detailed information about, and whose autonomous learning proved to be effective: they attained their targeted aims with self-study and self-education and that influenced their work or life in a way that they found it worthy to record. They are the real "masters" of autonomous learning, who acquired such knowledge with some kinds of particular independent learning methods that affected and changed their whole lives. In my study I would like to present the motivations, learning methods and results of those persons who represent the different types of autonomous learning and who developed them to be almost perfect, by giving examples from different eras of history: emosthenes gives an example for immersion and practising one special field, Saint Augustine for lifelong learning process, Marco Polo for getting knowledge when a person gets into a special, new life situation and Heinrich Schliemann for independent language learning.

\section{Demosthenes}

Demosthenes, the biggest Greek speaker was born in 384 B.C in Athens in a rich family. He was 7 when his father died, and although his father left a significant amount for him, but his fortune was consigned to his three guardians, who handled it inappropriately, so he could not get the careful education a free boy could get. The weak, often sickly child was cautioned by his mother and his educators from every strenuous activity, while his peers often mocked him, probably due to his speech defect.

According to the tradition, Demosthenes felt like doing the rhetorical craft as follows: the well-known Callistratus wanted to say a speech at the tribunal and this was greatly anticipated due to the reputation of the speaker and the significance of the discussed question. Demosthenes heard that his teachers also go to listen to the speech of the famous speaker, so he also begged until his educator took him with himself. Callistratus had an especially good day and he had a

\footnotetext{
${ }^{1}$ Loránd G. 1985;.Horváth I. 2004; Pordány S. 2006; Forray R. K. - Juhász E. 2009; Herczegh J. Tornyi Zs. Zs. 2009; Simándi Sz. - Oszlánczi T. 2013; Simándi Sz. 2015.
} 
great success with his speech. The young Demosthenes came to envy his glory when he saw how many people accompanied him and bestowed him with good wishes, but what really influenced him was to what extent a good speaker can influence people by only using his speech.

Then the young Demosthenes stopped his other studies and paid his attention only to learn rhetorics to be such a great speaker as Callistratus. He chose Isaeus, one of the well-known experts of inheritance cases to be his educator, although the famous Isocrates maintained a rhetorical school in Athens at that time, but Demosthenes either could not afford to pay the high fee of the school or he found Isaeus' rhetorical way more effective and more expedient from his point of view. Different sources mention that he also visited Plato's school, and he learnt a lot from the big philosopher, but its credibility is disputable. Nevertheless, he wanted to learn the art of rhetorics so much that he was not contented with the knowledge gained at the school, but, according to the report of Plutarch, he tried this also in his free time, so eagerly that he tried to outvoice the whizzing waves at the seaside with his speeches as a practice. Even, since - as we saw - being a poor orphan, he did not have the possibility to attend the best rhetorical schools, so by watching he secretly learnt the maneuvers of rhetorics used by Isocrates and Alcidamas.

When reaching his adulthood he thought that he was prepared enough and he held his first speech at the tribunal against the guardians who had tricked him out of his fortune. Though he won the lawsuit with great difficulty, he could only get back a small part of his father's inheritance. During the lawsuit he still managed to get the courage needed to public speaking and the suitable practice, thus trying the esteem and influence going together with the speaker profession he tried to publicly act in the field of public affairs, too. However, he was not trained enough for this: during his first public acts his words were lost in the noise, and people laughed at his unusual way of speaking, which was full of long circular blocks and complicated, hard to understand arguments. His voice was also found weak, his pronunciation was not clear, his breath sometimes slipped, and this disturbed the understanding of his speech, because it interrupted the circular blocks. His failure discouraged him and finally he stopped speaking in public.

But his friends scolded him for letting his talent and the knowledge he had gained so far lose so easily, so they encouraged him to teach himself and practice more. They also provided him with advice for speaking: „It is said that once when he failed and went home regretfully covering himself into his coat, a good friend, the actor Satyros joined him and started to talk to him. Demosthenes complained to him bitterly that though there was no other speaker who practiced that much as he, and that he almost wore all of his physical strength out, he could not win the grace of the public: even drunken people and ignorant sailors got listened to, but he was not taken into account. "You are right, Demosthenes - said Satyros -, but I will cure you out of your problem, if you are willing to recite some parts from one of the tragedies of Euripides or Sophocles by heart.» Demosthenes did it, Satyros repeated the performed parts with the manner and intonation befitted to them and what he recited was found totally different by Demosthenes immediately. He was convinced that the right performing way gives beauty and ornament to public speaking and practice means little or almost nothing if you do not take care of the phraseology and elocution of what you want to say."

So he dug himself into self-education again, by working out really particular methods of autonomous learning. He had an underground study room built - which was even shown at the time of Plutarch, three hundred years later -, to train himself more uninterruptedly and to have nothing to lure his attention away from public speaking. He retreated there for the whole day only to practice his performing way and train his voice, by giving an exceptionally big

\footnotetext{
${ }^{2}$ Plutarchus 1978. Demosthenes 7.
} 
importance to tonality and intonation. He even found out a really particular way of the urge for lonely learning: according to the tradition, he had his hair cut only from one side of his head many times through 2-3 months in order to avoid going among people, although he really missed company!

But apart from these weeks, he zealously carried out his ongoing affairs and held many speeches. But when he could free himself, he immediately went into his study and using the experience he gained during his work he further trained himself: he went through the certain cases and the connected sophistries in mind as well as those speeches he listened to, repeated them and articulated them into thoughts and circular blocks. He even corrected or converted his and other speakers' speeches in many ways.

Still, he had to face with another big problem obstructing his public speaking: according to our sources, he fought with a speech defect from his childhood and naturally, this meant a huge disadvantage in his public speaking. But according to the tradition he worked out a really inventive method to overcome this: he put pebbles into his mouth while reciting speeches to defeat his uncertain and erratic pronunciation by paying attention to them. He also strengthened his voice - think about what significance the strength of human voice had before the existence of electronic acoustic devices! - he recited speech parts or poems while running or going up a steep slope, though panting. Demosthenes was famous for vividly gesticulating while speaking, unlike the traditional sense. But this was also the result of autonomous learning: in his house he had a big mirror and standing in front of it he learnt the movement maneuvers fitting to the given topic.

He had to face also with the disadvantage of the great deal of challenging practices: many people thought he was not talented, but his knowledge and speaker preparedness were only due to the many practices. In fact, he always prepared his speeches carefully, many times he wrote them and did not really improvise, but this did not impair his speaker ability at all, according to the opinion of the posterity.

Finally, the tiring self-training ripened: after the tribunal cases he could step into the area of politics from 351 B.C. With his speeches of great effect he mainly sought to preserve the independence of the ancient Greece against the emerging new superpower, Macedonia. His speeches written against King Phillipos II, father of Alexander, the Great were called as philippics, which have been the widespread names of glowing, passionate indictments up today. His extensive, anti-Macedonian speeches urging for collaboration were not heard at first, but when the people of Athens at last realized that the greedier and greedier northern neighbour threatened them, they confronted with Macedonia indeed, by the influence of his speeches. Demosthenes reached the top of his speaking career this time: he was rewarded twice with a gold wreath for his speeches, which meant an enormous honour. His recognition as a public speaker and statesman was so big that even the defeat of Chaeronea in 338 B.C. being fatal for the Greek did not destroy his respect, and his devotees suggested two years later that he should be wreathed for his patriotic merits on the dionysian feast in the theatre. His political opponent, Aeschines protested against this, but the grandiose and overwhelming speech of Demosthenes, in which he reviewed his career so far, was such a great success that Aeschines had to leave Athens. Later, due to now obscure bribery charges Demosthenes was forced to exile, but after the death of Alexander the Great he was called back and again he organized the antiMacedonian Greek powers. The revolt was soon defeated and he, escaping from his opponents, committed suicide.

But his reputation did not disappear with his death: the respect for Demosthenes was huge even in the ancient times; he was especially respected among Roman people finding rhetorics important. His authority did not fade even in the Middle Ages, Janus Pannonius called the attention of King Matthias to the coming Turkish danger by translating one of the phillipics into Latin, and Demosthenes has been held as one of the biggest public speakers of world history 
even today. ${ }^{3}$

\section{Saint Augustine}

Saint Augustine did not train himself to artistic perfectness in a certain profession as Demosthenes, but his whole life can be seen as a continuous autonomous learning process. From his youth Augustine had a passionate thirst for "Truth", and during its search he consciously got to know the significant religious trends and movements of his era, hoping to find the true belief, and after his conversion he began to search the depths of Christian belief with the same zeal.

Augustine was born on the $13^{\text {th }}$ November, 354, in Tagaste, a northern-African town, in a smallholder Roman family. His father, Patricius was a pagan, and was only baptized shortly before his death, but his mother, Monica, who was later respected as a saint, was a deeply Christian believer. The extremely brilliant and susceptible Augustine finished his grammatical school in Madaura, after his primary studies. As a young man, he continued his studies in Carthago: he had lectures on rhetorics and law to earn money as a teacher of rhetorics. The youth of Augustine was similar to that of his peers: he found pleasure in entertainment, sometimes getting into bad companies and by not thinking about marrying his sweetheart he had a partner relationship, from which a child was born.

Despite his mother's wish, Augustine was not baptized; moreover, in this part of his life he did not appreciate Christian religion. However, during his studies he came across the work of Cicero, called Hortensius, contemplating about philosophy, which had a great impact on him. From this time on the extremely intelligent young man always had a primal restlessness in the depth of his heart, he wished to know the "Truth", this rushed him always towards knowing the different religions and ideological trends.

By paying his attention to philosophy and religious studies, he started to study the Bible, but he did not like its simple language, because he was used to the artistic style of the antique authors, so he stopped reading it. His attention was given towards other religions then. First he deepened into Manichaeism, since he seemed to find much truth in it. ${ }^{4}$ But after the initial enthusiasm, in some questions doubts started to obsess Augustine, so he tirelessly researched in the Manichaean religious books and analyzed their contents, as well as constantly bombarded the local leaders of the sect with questions: ,Since I have read several books of the philosophers and I preserved them in the depth of my memory, I compared some parts of them with the longwinded tales of Manichaeans. (...) Through almost nine years, as I was listening to them with a hesitating soul, watched them with a really strong, desperate desire when finally this Faustus [famous, high-skilled bishop of Manichaeans] arrives. The other Manichaeans, if I came across them and they had no idea to my questions, always promised him to me. That he will come. That in a personal discussion all my questions or even if I search the most difficult ones, can be easily revealed. (...) As soon I had the possibility, together with my friends I really availed his ears, at an available date for discussions. I gave him some of my exciting difficulties. I noticed at once that this man is not good at the free sciences." 5

The famous Faustus failed in the crossfire of Augustine's questions and soon he learnt the different sciences from Augustine. Meanwhile Augustine's career was rising steeply upwards: he became a famous teacher, moved from Africa to Rome, then for a while he settled in Milan, the emperor's place. But, despite all these, he felt neither tranquillity nor satisfaction; he only tossed between his secret wishes and expectations, the body and the soul. Disappointed in

\footnotetext{
${ }^{3}$ Castiglione L. 1982. 198-199.

${ }^{4}$ The Manichaeism is an Eastern religious philosophy what was very popular in the early Christian age in the Roman Empire.

${ }^{5}$ Augustinus 1982. V. III., V. VI.
} 
Manichaeism, he started to find the "Truth" elsewhere. For some time his attention turned towards studying astrology. He read eagerly every book he came across about astrology, and though he did not fully believe in it, but he could not reject its truth content, either. Though his friends drew his attention to the fact that this was only superstition and some established prophecies happened only accidentally, he - though he also tried to find proofs for these in the books - thought at that time that it could not be only speculation. Once one of his friends told him that a servant's child was born at the same minute when he was, but their lives continued in a completely different way: his friend lived his life as a rich man, while the servant stayed in a subject position all his life. This story really made Augustine think and started to study the destiny of twins. Soon he determined that though the time of their births is the same, their destinies many times go into different directions, so he rejected the science of astrology, too.

In Milan he met the Christian bishop, Ambrose. In the beginning, he only listened to the bishop's preaching due to his eloquence: Augustine, as a teacher of rhetorics, enjoyed this beauty very much, but soon after the truth of faith unwittingly penetrated into his soul as well: „Notwithstanding, I did not try to note his explanations, I just listened to his elocution - I did not believe there was a path to you, so I only cared with uselessness - the expressions that I liked introduced the content also to my soul, with which I did not care anyhow, but I could not divided them from each other. And while I was trying to understand with a willing soul how elaborately he was speaking, it also slipped into my soul that he was speaking the truth. And this gradually." 6

But he was still far away from the real truth. At that time he started to study the books of the neoplatonic literature containing some elements of Christian teaching. He did not feel this satisfactory, either; he missed certain things from the theories of neoplatonics, too. So he took the Bible again into his hands, especially the letter of Saint Paul, the Apostle, the words of which now penetrated his heart.

The one and a half decade of continuous searching, reading, talking, discussion brought its result: at last, in the Christian faith he found the "Truth" he wished so much. Now with his whole mind he accepted Christianity as the only one true belief, but a thousand of threads bound him to his old life, which it was not easy to get rid of. But soon it occurred due to a wonderful event: „Suddenly I can hear a boy or girl's voice from the neighbouring house. He sang and repeated this: Tolle, lege! Tolle, lege! Take and read it! Take and read it! (...) I pushed my tears back and jumped, because I saw nothing else but a sign from heaven to open the Scripture and read the first chapter I can see. (...) "Not in extravagance and drunkenness, not in beds and impudences, not in rivalry and envy, but get dressed into the Lord Jesus Christ, and do not treat the body as you wish.. ${ }^{7}$ I did not want to read further. It was not necessary. As I finished the sentence, as if the light of the certain calmness invaded my heart, the last shadow of doubt disappeared from me." 8

Following this he decided to take baptism, give up his teaching career and go back to Africa, where he formed a small community with his friends in Tagaste, in his birthplace. However, he did not stop the continuous self-training: but he did not search the different pagan religions and philosophies, but the depths of Christian faith. In his small community, his life included prayers, asceticism, studying the works of Christian writers, as well as discussing philosophical and religious topics with his friends.

Three years later there was a big change in his life: he was sanctified as an auxiliary bishop against his will in Hippo, then five years later, after the death of bishop Valerius, as a bishop. Then long years of continuous working came in Augustine's life, beside the tasks of bishopry he carried out significant theological researches, he took an active part in the polemics of his

\footnotetext{
${ }^{6}$ Augustinus 1982. V. XIV.

${ }^{7}$ Romans 13:13

${ }^{8}$ Augustinus 1982. VIII. XII.
} 
era, while always studying the Bible, to better understand the godly truths. About a thousand predications, 113 books and 218 letters from him were left to us and all of these prove that Augustine knew the Scripture extremely well. He died during the vandal siege of Hippo, on $28^{\text {th }}$ August, $430 .^{9}$

Augustine was one of the biggest figures of Christian theology, one of the four big western fathers of church. His work has had great importance until today, the reason of which we have to see mainly in the fact that through his whole life he educated himself by continuous selfstudy first in the field of pagan then the Christian religious studies.

\section{Marco Polo}

The Venetian Marco Polo, ,the globetrotter who saw and learnt so lot"10 spent almost 20 years in China in the $13^{\text {th }}$ century, in the court of Kublai Khan, while he acquired not only the languages and traditions used there but also the local writing that is very difficult for the European man. Unfortunately, from his travelogue - which was noted by one of his fellow prisoners in the prison of Genoa after his return - we do not get information about his learning methods, but, knowing his situation, in case of the acquisition of knowledge of Marco Polo we can obviously speak about autonomous learning, he counted as a real master in it, as is also proven by the recognitions gained at the court of the khan.

Marco Polo was born in a Venetian tradesman family in 1254. In his childhood he received a high level of education: he knew the classical authors and the biblical texts, and was also aware of the theological terms. From his later writings a figure of an interested, curious man is shown, who was interested both in the new natural and the human phenomena as well. His father and uncle left for the East in 1260 with commercial aims and at the end of a journey that lasted for years they reached Beijing, the centre of the Mongol Empire. Kublai Khan gave a warm reception to them and since he was briskly interested in the western world, he sent the brothers as delegates to the Pope, asking for Christian priests and holy oil from him.

The Polo brothers arrived home luckily, performed their duties and then started back to China, but this time they took the meanwhile grown up, 15-year-old Marco, too. In the East, Marco started to get to know the wonderful new world with an inexhaustible thirst for knowledge: „It happened that Marco, son of messire Nicolo, processed with a wonderful quickness to learn the traditions, language, military tactics of the Tatars. Indeed, he learnt many languages and four different writing methods in a very short time, so he could read and write in their language." 11

The 21-year-old Marco entered the Khan's service, who appointed him to several administrative positions. Since Kublai Khan was really satisfied with him, Marco became a kind of travelling ambassador and travelled almost all over China. His task was to make notes while travelling in the country and had to report to the khan, but it is obvious that it was not only his task that inspired him, but his own wish for knowledge made him learn more and more: „(...) messire Marco Polo learnt and could see more things with his own eyes about the different parts of the world as any other man who ever lived in the Earth, even so because he always kept his mind open for knowledge, with investigative attention and curiosity. "12

After spending almost twenty years in the Far-East, the Polo brothers, being afraid that after the death of the old Kublai Khan the new ruler may feel hostility towards them, decided to return home, and in 1295, after being away for 24 years they luckily arrived home. Marco Polo's travelogue showing eastern experience collected through almost a quarter of a century includes

\footnotetext{
${ }^{9}$ Diós I. 2002. 639-646.

${ }^{10}$ Polo, M. 1963. 39.

${ }^{11}$ Polo, M. 1963. 44.

${ }^{12}$ Polo, M. 1963. 45.
} 
loads of information concerning the medieval life in China, though some researchers question its reality, but some elements definitely show that the story of Marco Polo can be seen - if not in everything - basically authentic.

\section{Heinrich Schliemann}

Heinrich Schliemann was a legendary figure of the heroic age of archaeology, the discoverer of Troy and the whole ancient Mycenaean culture. The poor daydreaming German boy, who was passionately interested in antiquities, became a merchant, then a millionaire after many years of persistent work, which he could thank mainly to his language knowledge, beside his talent in trade. But as a penniless merchant assistant he could not afford to take language lessons, so he worked out a particular and - as his later career showed - very successful method for independent language learning, with the help of which - and of course by his unusual talent in languages - learnt a dozen of living and dead languages.

Schliemann was born on $6^{\text {th }}$ January, 1822 in the town of Neubukow, MecklenburgSchwerin. He spent his childhood in the village of Ankershagen, where his father was a priest. The little Heinrich was really interested in the antiquities already as a child: with his childhood love, Minna he got around the old buildings of the village and its legendary place - the Lake „Ezüstkehely" (Silver Cup), the ancient burial mound, the ruins of the medieval castle -, and this little boy having an extremely vivid fantasy really immersed into the world of old tales and legends. But mostly the Greek mythology tackled his imagination: his father, who loved antiquity very much, told him a lot about the lives and deeds of old Greek heroes, and the little Schliemann did not doubt them. Insomuch, at the age of eight he decided that when he becomes an adult he will not be calm until he finds the town of Troy.

Soon, however, the fate of the family Schliemann turned bad: the mother died, the father lost his job due to a disciplinary action. So the young Heinrich had to stop studying at the age of 14 and left school to be an apprentice in a chandlery. However, he did not forget about his childhood dream, his love for the ancient Greece strengthened more when one night a drunken, expelled miller lad entered the store and passionately recited some lines from Homer in Greek. Although Schliemann did not understand a word, the melodic language extremely influenced him: „,From that moment on I asked the Lord to have mercy on me and help me to have the possibility to learn Greek."13

But during an accident Schliemann was injured: he overstrained himself by lifting and spitted blood, due to which he was fired. He did not get a job anywhere, so in his ultimate despair joined a ship bound for America as a servant. But soon after the start, they got shipwrecked at the Dutch coasts. Schliemann did not want to return to Germany, even if in the Netherlands he had to face with the biggest misery - he could only survive the cold winter days if he pretends to be ill so he was taken to hospital. Finally, he became lucky: he managed to find a job as a delivery boy at a ship company in Amsterdam. Though he could make a living, he still lived in a great poverty: he lived in a miserable loft room, where he was cold in winter, while almost got heat stroke in summer.

Soon he recognized that if he learns the most important modern languages he could have a possibility for better jobs and break out of misery. But he was too poor to take normal lessons, so he worked out a really particular method to independently learn languages. In this he reduced the role of a language teacher - and thus the spending of money - to a minimal, practically used it for checking the gained knowledge, or even, in case of learning the Russian language he did not ask this kind of help, he could successfully learn it without this help. Schliemann's method went so well that he learnt a dozen of languages with the same method in his life, in a memorandum he even suggested changing the language teaching in schools in this way. What

\footnotetext{
${ }^{13}$ Schliemann, H. 1963. 42.
} 
was the secret of this really special and very successful autonomous learning method? We can get to know this best from his report:

„(...) I started to learn the English language with immense diligence, while the necessity led me to establish such a method that really facilitates learning foreign languages. This simple method first of all involves that you read a lot aloud, do not waste time translating, takes one hour a day from a teacher, makes written essays about interesting topics, corrects them with the help of the teacher, then learns them by heart, and recites the essay corrected on the previous day on the next lesson. Because I have rarely used my memory since my childhood, it was quite weak. Now, every time I can, I used every moment to learn, I even added extra time to my available time. In order to perfect my pronunciation I listened to the mass in the English church twice on Sundays, and I repeated every word of the predication to myself. To my delivery trips, even if it rained, I took the book with me and learnt a part by heart. I did not even wait in the post office idly, I always read. I burnished my memory this way, and after three months I managed to recite twenty printed pages of English prose texts by heart on the lessons to my teachers, Mr. Taylor and Mr. Thompson - to read carefully the text only three times was enough. I learnt Goldsmith's Vicar of Wakefield and Walter Scott's Ivanhoe by heart. I got so excited that I only slept a bit and spent the hours of awakeness to repeat once more the text learnt in the evening. Since man can think much more concentrated at night, these night repetitions were also very useful for me, I suggest this method to everyone. This way I could thoroughly learn the English language in half a year." 14

The so successful learning of the English language proved that his autonomous learning method worked perfectly and can easily be realized beside his work that needed little mental energy and gave much free time. Thus realizing his talent in languages and feeling the pleasure of successful language learning he decided to learn French alone, with this technique, and then - with taking less and less time - other languages came: „I followed the same method with the French language, too. This was done in the following six months. I learnt Fénelon's Aventures de Télémaque and Bernardin de Saint-Pierre's Paul et Virginie by heart. As a result of this continuous and overwrought learning, my memory became so perfect in a year that learning the Dutch, Spanish, Italian and Portuguese languages was not difficult, and to fluently speak these languages and not to have mistakes in writing, either, I needed only six weeks each." 15

Schliemann expected well: due to his language knowledge he managed to get a much better job: from a delivery boy he became a correspondent and accountant at another commercial company, for one and a half times as much salary. But he did not want to stop here, he thought he could promote if he learnt the language of Russia, which was an important trading partner and which language almost nobody spoke in the Netherlands at that time. But this was exactly what cause trouble: Schliemann found nobody who could have checked and corrected his Russian essays and pronunciation, so he really was forced to learn alone. Accordingly, he modified his learning method a bit:

„I thought if I could speak Russian, too, I could make myself more useful, so I started to learn again. It was hard to get the Russian books; I could only get nothing else but an old grammar book, a lexicon and a bad translation of Aventures de Télemaque ${ }^{16}$. But I tried in vain; I could not find a Russian language teacher, because apart from the Russian consul, $\mathrm{Mr}$ Tannenberg, who did not undertake my teaching, there was nobody in Amsterdam who spoke a word in Russian. So I was forced to start learning without a teacher, on my own, and in a couple of days I perfectly knew the Russian letters and with the available grammar book I learnt their pronunciation as well. Then I followed my older method, wrote short essays and then learnt

${ }^{14}$ Schliemann, H. 1963. 45-46.

${ }^{15}$ Schliemann, H. 1963. 46.

${ }^{16}$ Telemachus' adventures. Telemachus was Odysseus' son who started to look up his father after the

Troyan War. 
them by heart. But since I found nobody to correct my essays, and they were very bad indeed, I tried to eliminate the mistakes with different practices: I learnt the Russian translation of Aventures de Télemaque by heart. I had the feeling I could be faster if there would be somebody whom I could tell the adventures of Telemachus. So I hired a poor Jewishman who came to me for 4 francs a week and listened to my Russian speeches, from which he could not understand a word. (...) already after six weeks I could write my first Russian letter to Vasili Plotnikov, London agent of the M.P.N Malutin brothers, the big Moscow indigo dealers. It did not mean a difficulty to me to talk to him in his mother tongue, and also with Matvejev and Frolov, Russian traders, who came to Amsterdam for the indigo auction."17

After he finished learning Russian, he started to deal extensively with the literature of those languages learnt so far, by further training himself. He was not disappointed in his hopes: his company soon appointed him its representative in St. Petersburg and here he showed such a talent in trade that after a while he could found an own company. His company was successful, after some years of hard work he became a rich man. But he did not stop self-training: with the help of the well-established method he learnt Swedish and Polish. Meanwhile, he went around America burning in gold rush, where he could use his knowledge of different languages and gained a significant fortune. Schliemann invested his money further brightly: soon he became one of the richest traders of Europe, a real multimillionaire.

Now he could have a rest at last and began to realize his childhood dream. He never forgot the wonderful world of the Greek myths, nor the miller lad who recited Homer so passionately, so now freeing himself from the burden of getting a fortune he could start to learn the soadmired Greek language. Now he had money for language teachers, but despite this he used his own well-established self-training method in case of the Greek language, too, and used teachers' help only at a minimum, he learnt Romaic and Ancient Greek basically in an autonomous way, only with the help of literary works:

„In my whole life I had the desire to learn Greek. (...) In January, 1856, when the first news about the peace treaty reached St. Petersburg, too, I was unable to suppress the desire in me and started with the biggest diligence to learn. My first teacher was Mr Nikolaos Pappadakes, the second was Mr Theokletos Vimpos, both from Athens, where the last one is now an archbishop. Again, I followed my old, well-established method, to get the suitable vocabulary in the shortest possible time - which in this case seemed an even harder task than the Russian was -, I received the Romaic translation of Paul et Virginie, I read it, while I carefully compared every word to its French counterpart. After one reading, I learnt at least half of the words occurring in the book, after reading it once more I knew almost all without wasting one single minute to look the words up in the dictionary. So after six short weeks I coped with the Romaic language as well. Then I started the Ancient Greek, and I learnt it in three months and I could understand some old writers, first of all, Homer. "18

After getting the necessary language knowledge it was a huge pleasure for Schliemann that finally he could read his beloved ancient authors in original. He used these works to refine and burnish his style of Greek knowledge: he learnt some parts from them and used their figures of speech then in speaking and writing in Greek. ${ }^{19}$

After the Romaic and Ancient Greek he felt that it was time to continue learning Latin, which he stopped in his childhood. Indeed, in the knowledge of the Ancient Greek, Italian, Spanish and Portugues languages it did not cause any difficulties and really soon he learnt it. In the same year, in 1858 he went to Near East where he could again pay homage to his language learning passion and got to know a language completely different from those he learnt so far, the Arabic language. But here he applied another autonomous learning method: unlike the previous ones

\footnotetext{
${ }^{17}$ Schliemann, H. 1963. 47-48.

${ }^{18}$ Schliemann, H. 1963. 53.

${ }^{19}$ Schliemann, H. 1963. 53-54.
} 
he did not learn from literary works, but in a practical way, with the help of the word of mouth. ${ }^{20}$

As we saw, Schliemann learnt more than a dozen different languages during his life. Though his enormous fortune was due to the knowledge of the modern languages, he could gain world reputation not with these, but with the Ancient Greek language he loved so much. In 1871, only relying on Homer's epics, using them as travelogues, he managed to find the ancient town of Troy, under the Hissarlik-hill in the north-western corner of Asia Minor, the excavation of which proved to the contemporary scientists that Homer's epics really had some reality, which was denied by most. This was followed by exploring Micene and Tyrins in the Greek land, on the basis of ancient authors' writings - he managed to find the kings' tombs in Micene in a way that he interpreted the concerning part of Pausanias' work describing the area, which he read in original, otherwise than the scientists who earlier translated it! The exploration of Troy and the Micene culture totally unknown so far provided an everlasting place for Heinrich Schliemann among the brightest pages of anthropology, but without his talent, diligence and extremely individual language learning method he could never have achieved this.

\section{Conclusions}

The persons examined in the case studies present different types of autonomous learning. They achieved so high results in gaining knowledge on their own that these affected their whole lives and contributed not only to their professional successes, but also to the change of their whole destinies. We could get to know what kind of motivations led the persons doing autonomous learning masterly to successful autonomous learning, what learning methods they used and with the help of these methods what kinds of results they managed to achieve. So these case studies can contribute not only to the survey of the present forms, motivations and results of autonomous learning, but also to their better understanding.

\section{Sources}

Augustinus, A. (1982). Vallomások. Budapest: Gondolat.

Castiglione L. (1982). Az ókor nagyjai. Budapest: Akadémiai Kiadó.

Diós I. (2002). Szentek élete. I. köt. Budapest: Szent István Társulat.

Polo, M. (1963). Marco Polo utazásai. Budapest: Gondolat.

Plutarchus (1978). Párhuzamos életrajzok. Budapest: Magyar Helikon.

Schliemann, H. (1963). Életem, kalandjaim. Budapest: Gondolat.

\section{Cited literature}

Forray R. K. - Juhász E. (2009). A felnőttkori autonóm tanulás és tudáskorrekciós elkötelezödés. In: Nonformális - informális - autonóm tanulás. Debrecen: Debreceni Egyetem. 12-37.

Herczegh J. - Tornyi Zs. Zs. (2009). Az autonóm tanulás kutatásnak empirikus megközelitése. In: Nonformális - informális - autonóm tanulás. Debrecen: Debreceni Egyetem. 82-89.

Horváth I. (2004). Az autonóm tanulás kognitív összetevői. In: Modern Nyelvoktatás, 2-3. szám, 4047.

Loránd G. (1985). Önképzés és autonóm tanulás. In: Neveléselmélet és iskolakutatás, 4. szám, 69-71.

Pordány S. (2006). Az informális tanulás értelmezése és mérése. In: Fókuszban a felnöttek tanulása. Gödöllő, SzIE GTK, 25-33.

Simándi, Sz. - Oszlánczi, T. (2013). Rechtlicher Hintergrund des lebenslangen Lernens. In: Quality in the Context of Adult Education and Lifelong Education. Dubnica nad Váhom, Dubnica Technological Institute, 69-77.

Simándi, Sz. (2015). Lebenslanges Lernen im Dienst der nachhaltigen Entwicklung. In: Innovation und Erneuerung im Bereich der Erwachsenenbildung in Mitteleuropa. Dubnica nad Váhom, Dubnický technologický inštitút v Dubnici nad Váhom, 200-209.

\footnotetext{
${ }^{20}$ Schliemann, H. 1963. 55-57.
} 